УДК 629.4.027.11:681.518.5

Гол. інж. С.В. Бут (Південна залізниця), стари. викл. В.М. Петухов (УкрДАЗТ), наук. співроб. О.Ю. Катасонов (НВФ «ФЕРТА»)

Chief engineer Sergey V. But, senior lecturer Vadim M. Petuhov, researcher scientific Oleg J. Katasonov

\title{
СИСТЕМА КОНТРОЛЮ ТЕХНІЧНОГО СТАНУ БУКСОВИХ ВУЗЛІВ ДЛЯ ВАНТАЖНИХ ВАГОНІВ НОВОГО ПОКОЛІННЯ
}

\section{THE SYSTEM OF TECHNICAL STATE INSPECTION OF AXLE BOXES FOR FREIGHT CARS OF THE NEW GENERATION}

\author{
Представив д-р техн. наук, професор І.Е. Мартинов
}

Постановка проблеми. Створення сучасних вантажних вагонів вимагає забезпечення пробігу до 1 млн км без проведення ремонту. Це неможливо без використання сучасних систем контролю технічного стану відповідальних вузлів вагонів в експлуатації. Наприклад, вчасно не виявлені дефекти буксових вузлів призводять до важких наслідків - зламів шийок осей колісних пар при русі поїзда.

Запобігання таким випадкам можливе лише за умови раннього та своєчасного виявлення дефектів елементів підшипникових вузлів. Тобто контроль технічного стану буксових вузлів в умовах експлуатації $\epsilon$ важливою складовою забезпечення безпеки руху.

У цей час в Україні та інших країнах СНД почали успішно експлуатуватися букси 3 касетними підшипниками. Вони мають різні конструктивні особливості, використовують підшипники різних типів $\mathrm{i}$ виробників. Тому їх діагностичні параметри мають значне розходження у порівнянні із буксами, що обладнані типовими роликовими підшипниками. В результаті це призводить до помилки визначення їх технічного стану існуючими дистанційними системами теплового контролю букс, а саме: ПОНАБ, АСДК-Б та ін., тому що вони орієнтовані на контроль типових моделей візків вагонів, а їх оптична система не може змінювати свою орієнтацію в просторі у відповідності до розташування буксових вузлів різноманітних типів ходових частин вагонів.

Відповідно помилки такої апаратури призводять до необгрунтованих зупинок поїздів або пропусків несправних букс.

Ця проблема створює значні труднощі робітникам вагонного господарства, відтягує матеріальні та людські ресурси.

Виклад основного матеріалу. Ряд таких провідних світових виробників підшипників для залізничного транспорту, як SKF, FAG, Timken, в останні роки вирішують цю проблему шляхом оснащення буксових вузлів вбудованими засобами контролю. Це підвищує точність оцінки технічного стану, дозволяє виявити зародження дефекту ще на ранній стадії його розвитку. Також вбудовані засоби контролю дозволяють здійснювати моніторинг технічного стану букс незалежно від конструкції ходових частин, типу використовуваних підшипників та змащування. 
Тому для перспективного рухомого складу на кафедрі «Вагони» УкрДАЗТ разом 3 науково-виробничою фірмою «ФЕРТА» була розроблена та виготовлена експериментальна буксова діагностична станція - БДС [1,2].

Буксова діагностична станція призначена для контролю технічного стану буксових вузлів рухомого складу при русі поїзда 3 використанням технології безпровідної передачі даних. Комплекс БДС складається 3 наземної станції i бортових модулів, які монтують у кожну буксу. Датчики розташовують безпосередньо на контрольованих елементах букси. Структурна схема системи БДС наведена на рис. 1.

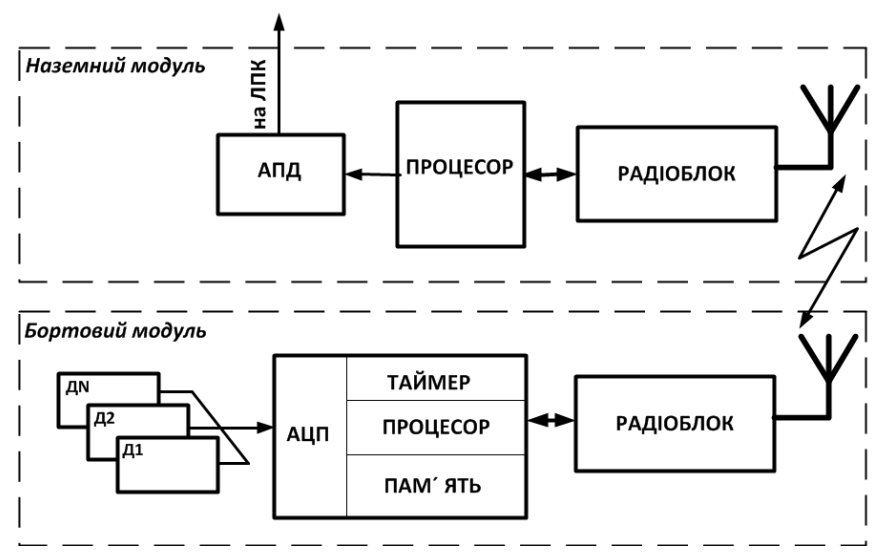

Рис. 1. Структура системи БДС:

Д1 ... ДN - датчики; АЦП - аналого-цифровий перетворювач; АПД - апаратура передавання даних; ЛПК — лінійний пункт контролю

У комплект наземного модуля входить два приймально-передавальних пристрої та ноутбук, що має відповідне програмне забезпечення.

Бортовий модуль має у своєму складі такі компоненти:

- мікроконтролер;

- приймально-передавальний блок безпровідного зв'язку;

- елемент живлення;

- датчики температури, частоти обертання і цілісності торцевого кріплення.

Дана система здатна здійснювати: контроль температури шийки осі; контроль цілісності торцевого кріплення, контроль частоти обертання колісної пари для виявлення іiї загальмованості, накопичувати статистичні дані про температурний стан букси, швидкості та пробігу вагона за певний період.
В рамках науково-дослідної роботи "Розробка системи визначення технічного стану буксових вузлів вбудованими системами контролю на ходу поїзда" для Державної адміністрації залізничного транспорту України згідно з програмоюметодикою випробувань, затвердженою Головним управлінням вагонного господарства Укрзалізниці в березні 2012 року, на станції Основа були проведені натурні випробування системи, у яких брали участь спеціалісти служби вагонного господарства Південної залізниці та вагонного депо станції Основа.

Випробовування проводилися для підтвердження можливості постійного контролю технічного стану буксових вузлів вбудованими засобами, а також можливості здійснення безпровідної передачі діагностичної інформації від буксового вузла на наземні модулі пункту контролю. 
Для випробувань БДС використовувався напіввагон 3 буксами, що мають торцеве кріплення гайкою М110. У кожну буксу вагона було змонтовано бортові модулі на торець осі РУ-1, (рис. 2) та закрито оглядовою кришкою. Термодатчик фіксувався також на торці осі, що забезпечило максимальну достовірність контролю температури шийки осі. Зовнішніх частин, що знаходилися б поза внутрішньою порожниною буксового вузла, бортовий модуль не має.
Два наземних модулі були розміщені 3 обох боків колії та з'єднані між собою USB-кабелем.

Програмою-методикою було передбачено рух дослідного вагона 3 різними швидкостями 3 отриманням діагностичної інформації від буксового вузла та зіставленням з реальними даними.

Схема розміщення елементів системи при проведенні випробувань наведена на рис. 3.

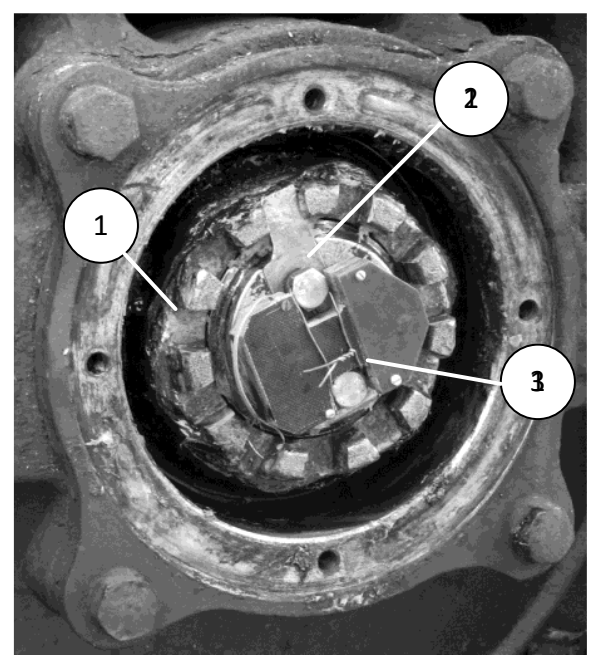

Рис. 2. Розміщення бортового модуля на торці осі РУ-1:

1 - гайка M110; 2 - стопорна планка; 3 - бортовий модуль БДС
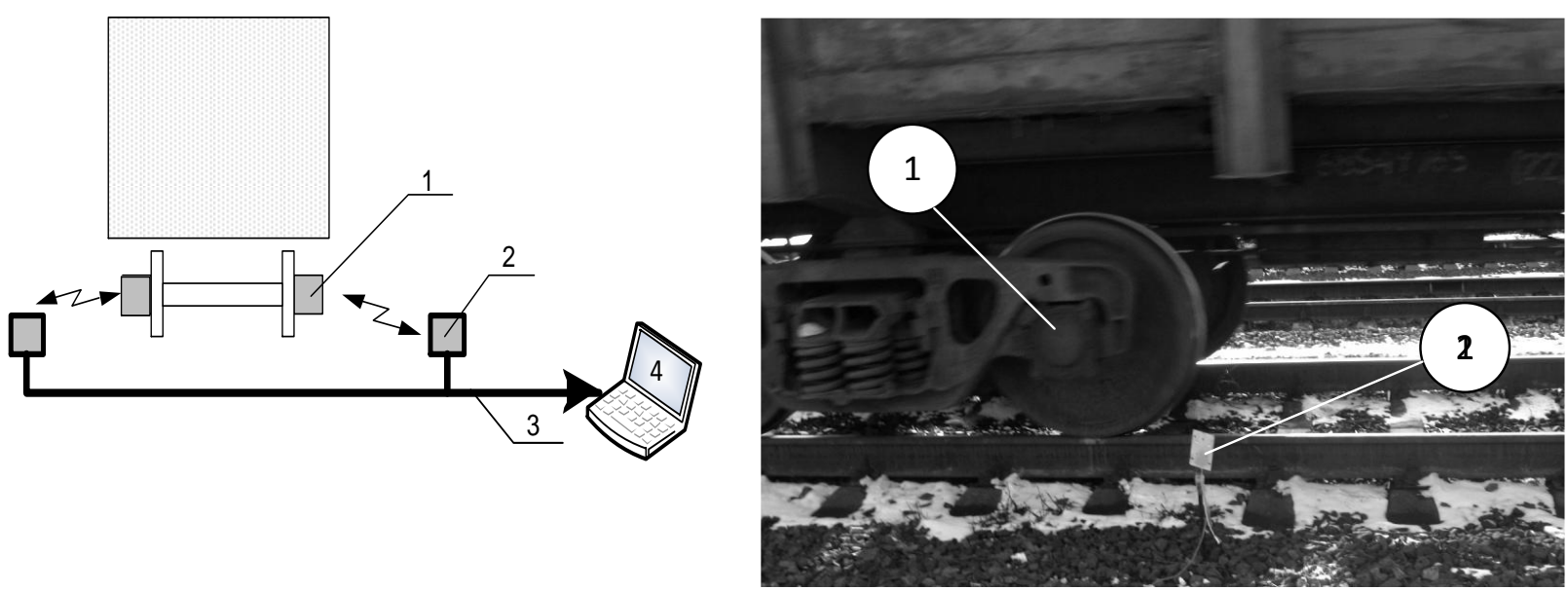

Рис. 3. Схема проведення випробувань:

1 - букса з бортовим модулем БДС; 2 - наземний модуль БДС;

3 - кабель USB; 4 - ноутбук 
Зміст пакета даних, що передавав бортовий модуль:індивідуальний номер букси; поточна температура вузла; максимальна температура вузла між попереднім і поточним постом контролю; темп росту температури; частота обертання колісної пари; стан торцевого кріплення букси.

Ця інформація відображалась на ноутбуці у вигляді таблиці і графіка.

Висновки. Застосування у вагонах нового покоління вбудованих засобів контролю буксових вузлів дасть змогу насамперед підвищувати безпеку руху й точність оцінки технічного стану букс, а також виявляти зародження дефекту ще на ранній стадії його розвитку. Такий контроль можливо здійснювати незалежно від конструкції ходових частин, типу використовуваних підшипників та змащування.

Натурні випробування вбудованої системи контролю букс БДС підтвердили можливість одержувати точні й оперативні діагностичні параметри безпосередньо 3 буксового вузла та максимально достовірно оцінювати його технічний стан. А також показали доцільність продовження роботи в даному напрямку та необхідність проведення експлуатаційних випробувань.

\section{Список літератури}

1. Петухов, В.М. Буксовая диагностическая станция [Текст] / В.М. Петухов // Зб. наук. праць. - Донецьк: ДонІЗТ, 2008. - Вип. 13. - С. 96-101.

2. Пат. №87333 Україна, МПК В61К 9/00. Пристрій для моніторингу температури букс залізничних вагонів [Текст] / Борзилов І.Д., Петухов В.М., Ходаківський А.М., Михалків С.В.; заявник i патентовласник Укр. держ. акад. залізнич. трансп. № а200704308; заявл.19.04.07; опубл. 10.07.09, Бюл. №13. - 4 с.

Ключові слова: буксовий вузол, контроль технічного стану, буксова діагностична станція, підшипник, торцеве кріплення, вбудований засіб контролю.

\section{Анотаціï}

Розглянуто проблему контролю технічного стану буксових вузлів вантажних вагонів нового покоління. Наведено результати натурних випробувань вбудованої системи контролю букс.

Рассмотрена проблема контроля технического состояния буксовых узлов грузовых вагонов нового поколения. Приведены результаты натурных испытаний встроенной системы контроля букс.

In article is discussed the problem of control of a technical condition of axle boxes units of freight cars of new generation. Results of the executed verification tests in situ built-in test equipment axle boxes units the freight cars. 